\title{
The Sunset Limited: A Study of Despair and Power of Faith
}

\author{
Prof. Naila Arshad
}

HOD of Department of English, GCWUS, Pakistan

prof.naila@yahoo.com

\begin{abstract}
This research paper intends to explore how Cormac McCarthy presents, in his play The Sunset Limited, opposite ways and approaches, i-e, pessimism and optimism, adapted by different modern men living in the modern age. This paper efforts to search how on one hand pessimism and the feeling of meaninglessness in life leads to atheism and nihilism, while on the other hand, power of faith, if once gained, can change life and its purpose, no matter what race or class one belongs to. This paper attempts to find that though both, life and death are realities but it is veryimportant to find justification either to continue living in a world of suffering and meaninglessness or to end life. This paper also intends to prove that the divine voice which propels towards hope and goodness, if heard only once, never loses power and charm even if some intellectual force with its rhetorical argumentation tries to move a man of faith towards despair and death.
\end{abstract}

Keywords: Pessimism, optimism, atheism, nihilism, hope, despair.

\section{INTRODUCTION}

The drama of the post-war period, from the 1950's onward reflects the dominant spirit of the age focusing on the prevailing social, political and religious situations with deteriorating values and attitudes. This post-war drama explores the darker regions of human psyche, the nothingness of human existence and the pessimistic approach towards life. The drama of this period also focuses on how to face the realities of life, how to take suffering as it comes and how to accept man's unheroic status in the absurd universe where he is forced to live.

The play, The Sunset Limited is based on confrontation of two contrasting ideologies faced by modern man, i-e, atheism and firm belief in God. The debate between Black and White in The Sunset Limited is the debate between believer and non-believer, between optimism and pessimism and between hope and despair. In a philosophical argumentation, both not only express their outlooks on life and religion but also attempt hard to convince the other.

Cormac McCarthy's play, The Sunset Limited, subtitled as A Novel in Dramatic Form, has been set in New York city. It opens in Black's apartment of a tenement building, situated in Black ghetto. It is a one-act drama which consists of one-scene conversation between two strangers named Black and White. White is an intellectual professor who has been badly affected by depression and as a result he has given up on life. In contrast to him, Black, a nigger from Louisiana, is a reformed prisoner who is convinced that he is being guided by God. The meeting and lengthy dialogue between them is the result of suicidal attempt of depressed White in front of The Sunset Limited, a subway train where he is saved by Black who brings him to his apartment. White is an atheist and is forced to suffer a crisis of faith after he has been saved by believer of God. White yearns to die and Black yearns to save the soul of White, taking it as a serious and important purpose of life. Therefore, White all along tries to leave the apartment for the train station to end the meaningless drama of his life; whereas Black all along tries to prevent White from doing so. The plot unfolds and develops with White's rude and flat rejection 
of Black's point of view, the invitation of the Black to eat something and the prison stories of the Black. It seems that the friendship may put an end to the suicidal depression. The climax is reached when White admits that he has lost all faith in God and brotherhood and persistently demands to be released. Understanding his failure to stop White from killing himself, Black finally unlocks the door. Though the play ends with White's intellectual triumph and Black's rhetorical defeat, Black is also victorious in remaining unchanged and committed to his strong belief in God and mankind.

The title of the play The Sunset Limited is, in fact, the name of an Armtrak train which rides toward West. This train actually goes from Louisiana to California. Riding westward can make this train named The Sunset Limited, to be symbolic of the via for taking the final journey which is 'death'. It means travelling west of the real sunset can be a symbol of White's decision to embrace death by throwing himself before this train. White decides so because in his opinion if ultimately death has to come, whether sooner or later, then it should be rather met with quickly instead of lingering in the world where life has become meaningless. The selection of names Black and White by McCarthy stand for opposing forces, i-e, religion and no-religion.

This thought-provoking exchange of dialogue is the study of the depth of complexities prevailing in modern man's ideological differences concerning despair, existence and meaning of life, brotherhood and power of faith.

The story told by Cormac McCarthyin The Sunset Limited, has been in many respects influenced by Samuel Beckett's masterpiece, 'Waiting for Godot' (1956), especially for having two major characters to deal with the conflict, using the technique of conversation throughout the play, focusing upon the theme of 'hopeless hope' and sharing suicidal tendency in characters. But Cormac McCarthy's individuality is obvious in his development of the plot in the play. It is clearly described with White's decisiveness not to wait for God as he does not believe in him rather he selects the path of suicide to leave the world while frequently mentioning of having to go (almost twenty times in the play). Same is the case with Black who is all for optimism and tries his utmost to prevent White's suicide fail, weeps in the end because of the rhetorical victory of White over him, but it is he who proclaims, at the same time, his strong and firm faith in God and His word whether He speaks to him again or not.

\section{THESIS STATEMENT}

This research is a study of despair and power of faith in modern and post-modern age while focusing on Cormac McCarthy's unique way of dealing with belief system of the opposing outlooks on existence in The Sunset Limited.

\section{RESEARCH QUESTIONS}

- How existential Christianity conveys optimism through the concept of 'brotherhood'?

- How the belief system of the opposing outlooks on existence, i-e, despair and power in faith, stem and which is stronger though none is swayed?

- What makes Black reaffirm his power of faith in the goodness even after his rhetorical defeat in The Sunset Limited.

\section{THEORETICAL FRAMEWORK}

The most influential post-modernist,Jacquis Derrida's theory of deconstruction can work as a critical tool of literary analysis of The Sunset Limited by Cormac McCarthy. Derrida's one skeptical procedure is to subvert the innumerable binary oppositions e.g. soul/body, right/wrong, hope/despair, white/black, etc., which are essential structural elements in logocentric language. His theory is applicable as the play is a debate presented 
in words and language by two completely opposite persons. Black stands for evangelical Christianity and Whitepromotes the idea of death to get rid of problematic and painful life in modern age. Outwardly White wins the debate but in reality Black is the winner who becomes superior by saving his soul and by being still firm to continue his mission in the service of God (by helping humanity).

\section{METHODOLOGY}

In this qualitative research, keeping in mind the social, political, cultural and religious background, textual analysis of Cormac McCarthy 's The Sunset Limited has been done by applying different techniques and methods to find major and universal ideas hidden in words, phrases and sentences. The play has been analyzed as a study of disillusionment on one hand, and strong faith in God on the other hand.

\section{LITERATURE REVIEW}

According to Manual Broncano, both characters in Cormac McCarthy's The Sunset Limited, engage in an extended discussion on the nature of belief and hope, as if they reproduce McCarthy's inner debate between the need to believe and the daily evidence that prevents such belief. Broncano compares and contrasts both the characters by writing that Black is ex-convict with a record of violence who heard a voice after which his life became a sustained effort to help others. Broncano points out that Black, despite all evidence to the contrary, holds firm to faith in the existence of God. On the other hand,White has become perfect nihilist, paralyzed by the recognition of the senselessness of a life in which "every road ends in death. Or worse"(sunset 137). Steven Frye supports the idea that existential Christianity is directly expressed in the character of Black in The Sunset Limited. According to John Cant, the debate presented in The Sunset Limited is a philosophical debate concerning the justification for continuing to live in a world of meaningless suffering. Lydia R. Cooper in her criticism states that in The Sunset Limited, both Black and White acknowledge the connectedness of humanity but for White that mystical unity is only for despair whereas Black believes that there exists a sameness that connects them, i-e, the sameness of mystical divinity in all human forms. Erik Hage opines that Black and White have opposing outlook on existence. And Black possesses the more positive outlook of the two because he promotes the teachings of The Bible while White is an atheist. Erik Hage believes that in the end none is swayed from his conviction, neither White from his intent to end his life nor Black from his unwavering faith in God and His word.

In Broncano's judgment it cannot be ignored that after holding a long conversation with a professor, Black might have gained further strength to save and help others. In this sense, this event can be taken as an additional experience (though painful) in the learning process of life for Black on his way to goodness. Steven Frye has rightly supported the idea that existential Christianity has been directly expressed in the character of Black. In fact, Cormac McCarthy nowhere forces the reader to get impressed by Black or White's ideology. He provides equal opportunity to both of them to express their views on life, death, pain, existence, music, junkies, Bible and God. He makes Black declare that though he went to jail house after killing a man yet now (after receiving his call) the existence has become important to him. Now to help his fellow human beings has become the purpose of his life. In this sense he has been presented as a brave man who accepts the challenges of life whereas White is a coward who cannot stand the challenges as well as the faith and follows the path to death. As far John Cant's opinion is concerned, to him Black stands for life and White is the man of death. John Cant declares Black to be the existential hero. It cannot be ignored that though the whole play is pregnant with meaningful sayings regarding social conditions in modern age and difference of opinion on religious outlook of different people belonging to different classes yet Cormac McCarthy's extraordinary worth lies in his final decision to end the play asserting the power of faith in all circumstances.

After the study of some selected works already done on Cormac McCarthy's The Sunset Limited in which other writers have presented comparative study of the characters and their ideologies on despair and powerfulness of 
faith, it can be stated that though this work is highly valuable for new researchers in enhancing the knowledge on existentialism, religion and many other important aspects related, yet much work is still needed from the perspective of character analysis in this regard. Therefore, this research has its significance for focusing on character -analysis to find not only McCarthy's social, political and religious portrayal of modern society but also to pave the path for future investigators to work on McCarthy's viewpoint presented in the last monologue of the Black who has strong faith in God.

\section{ANALYSIS}

The Sunset Limited by Cormac McCarthy is an intelligent debate of philosophical nature about faith in God and the purpose of life on one hand and atheism and meaninglessness of life on the other. The choice of names for characters, Black and White, makes clear the dichotomy to be presented by McCarthy. As the play opens in Black's apartment, the preliminary dialogue discloses that White, a professor, in his extremely depressed condition has tried to kill himself by leaping himself in front of New York's subway train, The Sunset Limited. As he tries to make the fatal jump a man named Black, an ex-con but now changed into a deeply religious person, saves him. Sitting at dining table in his apartment, Black interrogates White in order to find the reasons of his suicidal attempt. After getting answers to some of his questions Black is shocked to find that White has no interest in personal beliefs or values. Here McCarthy shows importance of sleep also. White is so depressed that he has not slept last night and as a human being Black can understand the negative influence of sleeplessness on a person who is already disturbed. White does not regard his birthday to be a special day, therefore, he does not mind making it his death day. White considers birthdays dangerous like Christmas. The mention of hanging things symbolize actual 'hanging' of man or Christ. That is why at this point he at once declares to "I'v got to go" (p. 6). Through questioning White frequently, Black gets familiar with the way of thinking of educated people like the professor. When White insists upon going, Black's decision to go with him (even if white is going home) is, in fact, his effort to resist White's approach again towards death. But White's saying that he cannot go home with him makes Black realize and tell plainly that White can come to his home but he cannot go to White's home.It is obvious here that Black possesses the quality to face reality. He simply remarks that White people do not like black folks in their area. This reference has been made by McCarthy towards racism prevailing in the modern developed society of advanced country like America.

White, being a totally disillusioned man, wonders why Black cares so much about a stranger's life. He questions Black who has appointed him to be his guardian angel. In fact, White is intelligent enough to understand that Black believes Jesus has appointed him as White's guardian angel, Jesus has made him leap into Black's arms and Jesus has made the events occur the way they take place that day, that is why he asks Black if he really thinks that Jesus is in his room. Black's beliefin the presence of Jesus in his room is so strong that he does not "think" (p.8) but is sure that Jesus is present in his room. At this point White asks if Black can see Jesus and Black's reply is very simple, plain and innocent. He says that he can't see Jesus but he hears him daily; though he is not so particular about hearing voices, not even of his own, yet he has "heard" (p.9) Jesus. Black explains how after hearing the phrase 'lingering scent of divinity'(p.9) uttered by some black preacher on radio, he got interested in religion. Here McCarthy gives importance to words which have the ability to influence people.

Cormac McCarthy makes language the major strength of his play The Sunset Limited in which there is no action but only the use of accurate, vivid and moving words with deeper meanings.At one place after questioning White and making calculations Black points out that over the course of White's whole life he has read almost four thousand seven hundred and twenty books containing worldly knowledge but he has not read one book the Bible which teaches how to live in the world. Perhaps at some stage White has read some parts of the Bible but he has not read it the whole as he has read other books. To differentiate between two books it is essential to read the both. It seems that Blacks wants to bring White to the point to make him read the complete Bible thoroughly even if to differentiate with other books only. When White declares War and Peaceto be a good book Black wants to know if difference of authors makes any difference in White's point of view. He also wants American Research Journal of English and Literature 
White to define "a true book" (p.12). At this, White replies that a history book like Gibbon's Decline andFall of the Roman Empire might be a true book because, according to him, it is about actual events that have happened. Black wants to know if one of these books is true and White's response is that in historical sense none of these two books is "true", he means not even the Bible. Actually, Black wants him to decidedly declare which of the two books is good and true one. White wants to avoid comparison hence avoids the reading of Bible. Black asks if White agrees to the saying of the Bible that it is the greatest book ever-written, and he agrees to it. Black then asks a shaking question; if White has read good books then why he has not read the best book? At this question White feels the need to go instead of providing the answer.

In The Sunset Limited, McCarthy presents White as an atheist. While discussing how Black comes to rescue White at his amazing leap, White clearly remarks that Black believes in angels whereas he does not. Instead of angels he believes in cultural things-books and music. Books and music, according to White, are foundations of civilization, therefore, these have value to him. But even these have lost value now. Although White does not believe in beliefs yet he believes in the sunset limited. It seems to have become a metaphor of death for him. In response to another valuable and relevant question about having a friend, White gives his opinion about friends who do nothing except eating together. White is not clear about the best form of friendship either because he has no real friend or because he himself is not a good friend to anyone. White tries to get released soon from the life-saving, soul-saving and toward religion-tilted trance of Black. He falsely tells Black that he wants to go home to which black does not believe. At this, White calls himself a prisoner and Black comments that before coming to his home White has already been a "Death Row prisoner" (p. 16). White tells about his father who was a lawyer and how he didn't go to see his dying father in suffering and pain from cancer because he doesn't want to "remember him that way" (p. 17). This shows another aspect of White's character that he is an escapist who tries to escape the bitter and painful realities of life. That is why he wants to put an end to his life. When Black mentions light- good and true light- Black does not want to see or feel this light being turned into a nihilist and atheist.

Black is a loving man and its proof is that he calls White "brother" (p. 18). Now White questions Black and comes to know that Black has spent time in jail on the charge of murder. In reply to the question about marriage White receives only "Oh man" (p. 18). When he asks about his children Black tells that his two boys and all the other members of his family have died. He further tells that he has spent seven years of hard time during which he smacked many people. He tells that he lives in this building for the sake of junkies and crackheadsdespite their stealing habits. Black misses one thing here and that is music. He tells honestly that he does not want to have a television but music. At this White calls his place to be terrible place with horrible people. He thinks junkies not to be "worth saving" (p. 20) people.Black argues that though life is long and dry but times often change. He tries to talk about hope in life but White says that it is bad life and at once says that he has to go. Then he insists upon the need to go in any case. Black allures him to listen to his jailhouse true story in order to stop him from going to death and White agrees to listen but the true story only. Black narrates the story giving detail of event which took place in the jail. One day a nigger misbehaved with the Black and he tells how the fight started, how he got injured, how he injured others, how someone pushed the button of alarm, how the guard came and was about to shoot him but the lieutenant came and saved him. Almost half of his blood was lost. Nobody died. He was about to die and they operated him. When he came into senses he felt hurt with two hundred and eighty stitches. Still he had leg irons and was hand cuffed to the bed. In this condition he heard the clear voice saying, "if it was not for the grace of God you could not be here" (p. 23). Black says it was then that he got changed. Black says he does not know why God spoke and White comments that He is an opportunist. Both the characters differ in their views about killing oneself, happiness and suffering. Continuing to convince White, Black points out that according to the Bible, God has forbidden from committing suicide. To White, happiness is ridiculous. It is nowhere. In his opinion suffering and human destiny describe each other. But Black rightly points out if there is no pain in one's life how can one know what happiness is. 
In The Sunset Limited, White stands for reason and Black stands for evangelical Christianity. White has been following throughout his life the prevailing social order and culture but without paying heed to any religion. He seems unaware of his problem. As far as religion or God is concerned he clearly says that he does not want to be loved by God. Now even culture cannot console his soul. He does not want to see the people again whom he has known in his life. Without any hope of renewal he feels committedto suicide as only via to end his existence. On the contrary, from the day Black has received his call he has embraced Christian simplicity and whatever divine knowledge he has, has been received directly from the Bible. White has been so deeply disillusioned internally that he thinks that in search of meaning to the existence of man, he has spent his whole life futilely. But Black has given meaning to his life with purpose of serving his fellow beings, therefore he feels comfortable with his faith. White, a book-loving intellectual is thoroughly tilted toward death through suicide, whereas Black, a people-loving ex-con, finds life meaningful and worth-living (having faith in God) not only for himselfbut for others as well. If White is an epitome of cynicism then Black is an epitome of optimism. If White is archetype of reason then Black is archetype of faith. If White is an embodiment of despair then Black is an embodiment of hope. Both of them have opposing temperaments. In fact both of them try to convince the each other. Black does not want White to leave the apartment due to fear that he will commit suicide. He takes it as a challenge to saveWhite's soul by preventing his suicidal killing. At the same time White, with the help of his intellect and reason tries to persuade Black that in modern age there is no God. For him The Sunset Limited (train) is a metaphor for the journey of life but he does not want to take it to the end. Quite opposite to him, Black feels happiness in getting what we need instead of what we want.

Because of his experience of pain and suffering in life around him White remarks that to stop worrying is not an easy task. Black has tasted the spiritual joy after helping others. That is why, according to him, life gives light and one can make one's life everlasting. Black wants White not to leave and for this purpose he is ready to change the topic and can discuss baseball. He decides to bring something to eat. White agrees to have some coffee and mentions again to leave after that. On the question of his relationships with colleagues, White replies that he loathes other professors and they loathe him. Here Cormac McCarthy presents another point of opposition. In the greatest country of the world the poor uneducated people coordinate with each other but educated people lack this coordination. White further philosophizes that he loathes them and because he is like them, therefore, he loathes himself also. It is a painful thing that White has already tried psychological treatment for his "suicidal depression" (p. 37) but even the drugs have done nothing. At this stage of discussion Black makes difference between different travelers by explaining that one (Black) stands on platform hundreds or thousand times to reach the workplace and another (White) stands on the same platform for another purpose. He means that one's purpose is to participate in life-activation while the purpose of the other is to put an end to life itself. On the issue of cursing unknown people on train, White admits that he does not like people. Here too, he is opposite to Black who helps people and believes in brotherhood. In response to Black's next question that though he does not like people yet he never hurts them, White agrees. Then Black comes to his actual point and wants to know howcan such a manhurt himself. To White it is not the same thing as they are they and he is he.Black believes that there are no Jews, no Whites, no niggers, no men of colour but only one thing and that is Humans. Black is a good learner also. Whenever White utters some new words Black asks meaning. Black brings food and then says Grace (prayer). He thanks God for the food and all other blessings. Black is not an ungrateful person. He thanks God for saving professor though he does not know why he is needed. White tells him that his prayer is good then says this is "very good" (p. 43). In Black's opinion jumping before the Sunset Limited is the worst thing White has tried. Then they debate on the topic of civilization. Black gets surprised to listen White who explains that history is full of saga of bloodshed, greed and folly. He is sure that humans will not be here much longer. Black wants White to consider other people to be his brothers during his despair and self-destruction period. He appreciates White's intelligent reasoning. He has the opinion that the light of faith is everywhere around man who just has to see it. At this White declares plainly that he has no faith like Black. This declaration shows their difference on religion. In White's opinion different people have different reasons 
to go toward suicide and his own reason in this regard is gradual loss of make-belief. Black's desire to educate the people (towards positive side of life) who try to commit suicide, is called "facetious" (p. 35) by professor. When many things seem opposite and contrasting with White's idea, Black asks about the world White knows. White's hopelessness about world is obvious when he describes the world as a "forced labour camp" (p. 52) from which the workers are daily executed. According to him, the efforts that people undertake to improve the world, make it worse. Black takes notice of note of hopelessness and despair in the talk of White and White admits that only death can end pain and to die quickly under a fast-moving train means totally painless death. White refuses to compare his life with Black's at Black's suggestion and feels the need to go. Black wants him to postpone his suicide for one night at least and to White it depends on if he does not commit it today. It means he is going to commit it today. Here Black regrets for not having the words that can serve to reach the heart of White. McCarthy has given importance to language here.

According to White, the worst thing of his life was when a Black saved him from dying. If McCarthy shows rhetorical superiority of White in The Sunset Limited then he shows the extraordinary ability of Black to make White utter certain facts about him because of his questioning like a psychiatrist. Black adapts preaching style now advising to find an excellent world by being decent and loving to the fellow beings. In this way one can save oneself and feel relieved for not following the path to suicide. But White still insists to go because he does not believe in the world. Here White explains that he desires "darkness" (p. 57). He prays for "death" (p. 57). As dead have no existence therefore no community, that is why he has idealized Death, which will provide him with silence, Blackness, Loneliness and Peace. Only heart-beat is between all these peace-providing things. He believes that his state of mind is not pessimistic view of the world, it is rather the world itself. According to him evolution brings awareness of futility. White pleads his case in favour of his suicidal act by saying if people see what the world and their lives in it truly are for, they will select to die as soon as possible. In his final monologue, White proclaims clearly that he does not believe in God. There is no religion which prepares one for death. All talk about justice, brotherhood, eternal life, good God and the church preaching prepares people for more life with dreams, illusions and lies. Only if the fear of death can be banished from the hearts of people they would not live a day. Every road, every friendship, every love, betrayal, loss, suffering, pain, hideous lingering illness ends in death. The true brotherhood is in sharing pain. He condemns the idea of desiring this life which gives only pain and suffering. Black agrees to him with lowered head. White rising to go declares himself to be a professor of darkness in day's clothing. He is not in need of God's love or forgiveness instead has only hope of nothingness. He asks Black to open the door and finally exists. Now Black asks God if He wanted him to help White then why didn't Hegive him the words with which He has awarded White. While weeping and kneeling back and forth, he reaffirms his obedience to Him and firm belief in Him and that even if he does not speak to Him again, he will keep the word.

In the beginning it is Black who leads the dialogue with hope of life and light but in the end it is White who makes the play take a darker turn with his frightening despair. The initially plausible dialogue turns into apocalyptic near the end. In The Sunset Limited, Cormac McCarthy masterfully reveals the importance of rhetoric and oratory by proving words to be the only medium of meaning, words-which on one side have so much darkness with them to drive one towards death and on the other side, make another to hold a complaining exchange of talk with God.

\section{OUTCOME}

After a deep study it has been found out thatThe Sunset Limited by Cormac McCarthy is a study which focuses on two ways of thinking about life, one presented by an educated man belonging to civilized world and having variety of vocabulary to interpret his views and for whom life has become an empty shell which is now void of interest and has pushed him to the verge of suicide. The other is presented by an uneducated man belonging to the world of uneducated junkies, having a violent past, who after a prison-fight in a half-dead state has heard the voice of God and because of it cherishes not only for himself the warm light of life but also wants to throw American Research Journal of English and Literature 
The Sunset Limited: A Study of Despair and Power of Faith

its rays on his fellow beings without distinction. This research reflects that love of God and firmness of faith can convert a convict into a skillful and profound preacher of Christianity. This research proves the importance of language, especially the use of words to express ideology in an effective way while dealing with serious matters like religion, despair, existence and faith. Hence, promoting the idea of having firm belief in power of faith. This study also leaves the doors open for future researchers on one hand to enter into a new realm to promote the idea of simple and kind preaching with forceful rhetorical argumentation instead of punishment and hatred towards criminal class in society, and on the other hand to introduce optimism (which McCarthy calls "light") even in the worst circumstances at every level, in order to save the souls of extremely depressed people which is the need of the hour.

\section{REFERENCES}

1. Beckett, Samuel. Waiting for Godot: New York: Grove Press, 1954. Print.

2. Broncano, Manuel. Religion in Cormac McCarthy's Fiction: Apocryphal Borderlands. New Year: Routledge, 2014. Print.

3. Cant, John. Cormac McCarthy and the Myth of American Exceptionalism:New York: Routledge, 2008. Print.

4. Cooper, Lydia R. Cormac McCarthy's Heroes: Narrative Perspectives and Morality in the Novels of Cormac McCarthy::, 2008. Print.

5. Frye, Steven. The Cambridge Companion to Cormac McCarthy: New York: Cambridge University press, 2013. Print.

6. Hage, Erik. Cormac McCarthy: A Literary Companion: USA: McFarland and Company Inc., publishers, 2009. Print.

7. McCarthy, Cormac. The Sunset Limited: New York: Vintage Publishers, 2006. Print.

Citation: Prof. Naila Arshad, "The Sunset Limited: A Study of Despair and Power of Faith" American Research Journal of English and Literature, vol 3, no. 1, 2017, pp. 1-8.

Copyright (c) 2017 Prof. Naila Arshad, This is an open access article distributed under the Creative Commons Attribution License, which permits unrestricted use, distribution, and reproduction in any medium, provided the original work is properly cited. 